\title{
Disappearance of sorghum stover polyphenols and browse condensed tannins in the sheep gut
}

\author{
A. V. Goodchild ${ }^{1}$ and N. P. McMeniman ${ }^{2}$ \\ 1 Intermational Centre for Research in Dry Areas, PO Box 5466, Aleppo, Syria \\ ${ }^{2}$ University of Queensland, St Lucia, Australia
}

\section{Introduction}

The fate of antinutritional factors in the digesta as they pass along the gut may help to explain their effects on sites of digestion. Condensed tannins, e.g. those in Lotus pedunculatus, reduce rumen degradation of carbohydrates but increase the outflow of digestible amino acids from the rumen (Barry, Manley and Duncan, 1986). The stover of birdresistant (BR) sorghum contains monomeric polyphenols in its leaves which are related to the condensed tannins. However, they reduce both fermentation in the rumen and absorption of amino acids from the intestine (Reed, Tedla and Kebede, 1987).

In an experiment with sheep, we compared a BR sorghum stover-based diet with the same diet supplemented with leucaena (Leucaena leucocephala) or mulga (Acacia aneura). Both leucaena and mulga contain condensed tannins, and leucaena also contains flavonol glycosides. Flows of digesta through the abomasum, ileum and faeces were estimated and digesta were analysed for proanthocyanidins, Klason lignin and Klason lignin nitrogen.

\section{Material and methods}

Six sheep cannulated in the abomasum and terminal ileum were fed, for 28-day periods, with: (a) a basal diet of chopped BR sorghum stover $(500 \mathrm{~g}$ dry matter (DM) per day) with urea and minerals; (b) basal diet and leucaena (105 g DM per day); and (c) basal diet and mulga (328 $\mathrm{g}$ DM per day). Leucaena and mulga each provided $4.0 \mathrm{~g} /$ day acid-detergent-soluble nitrogen.

In the last 3 days, flows of digesta were calculated using the double-marker method of Faichney (1975), the fluid marker being ruminally infused chromiumEDTA and the particulate marker Klason $(72 \%$ sulphuric acid) lignin corrected for nitrogen content (see below). Proanthocyanidins (PCy) in freeze-dried fractions of food and digesta were measured in a spectrophotometer at 480,547 and $558 \mathrm{~nm}$ after heating in 95:5:5:5 butan-1-ol: $\mathrm{HCl}:$ methanol : water at $95^{\circ} \mathrm{C}$ for $2 \mathrm{~h}$ (Bate-Smith, 1981). Mulga condensed tannin was used as a standard, and the wavelength of $480 \mathrm{~nm}$ allowed a correction to be made for the pigments in sorghum stover.

\section{Results and discussion}

The apparent digestibility of the organic matter of all rations was 0.46 to 0.53 , of which about 0.6 was digested in the rumen. In the faeces, uncorrected lignin recoveries were $1.00,1.14$ and $1.27 \mathrm{~g} / \mathrm{g}$ and lignin nitrogen recoveries were $1.31,1.55$ and $2.08 \mathrm{~g} /$ $\mathrm{g}$ for the respective diets. Artifact lignin, calculated as the ratio of the added lignin nitrogen to the added lignin, contained $74 \mathrm{mg}$ nitrogen per $\mathrm{g}$ in both leucaena and mulga. This was over three times the nitrogen concentration in lignin, but less than the nitrogen concentration in Maillard products (Van Soest, 1982).

The disappearance of browse PCy along the gut was large: 0.4 or 0.5 before the abomasum, about 0.8 before the ileum and 0.9 in the whole gut. This contrasted with the disappearance of BR sorghum stover pigments, despite proportionately over 0.85 of them being soluble in acid detergent. The pigments were estimated in the PCy test, and were readily distinguishable from browse $P C y$, being yellowbrown and having an absorbance peak at $480 \mathrm{~nm}$.

As may be seen in Table 1, disappearance of PCy at various sites in the gut were quantitatively similar to increases in artifact lignin in both browse species. Conversion of condensed tannin in or around the abomasum into an inert lignin-like artifact would explain why it modifies rumen degradation more 
Table 1 Quantities of artifact lignin (assumed to contain $74 \mathrm{mg}$ nitrogen per $\mathrm{g}$ ) and proanthocyanidin (PCy, mean of 547 and $558 \mathrm{~mm}$, using inulga tannin standard) passing through sites of the sheep's gut

\begin{tabular}{|c|c|c|c|c|}
\hline & Fond & Abomasum & lleum & Faeces \\
\hline \multicolumn{5}{|l|}{ Sorghum stover } \\
\hline Organic matter (g/day) & 450 & 317 & 283 & 219 \\
\hline Pigments (Absorbance units) & 5.0 & 5.7 & $5 \cdot 1$ & $5 \cdot 0$ \\
\hline Artifact lignin (g/day) & $-1 \cdot 3$ & 1.9 & 0.4 & 1.2 \\
\hline \multicolumn{5}{|l|}{ Leucaena } \\
\hline Organic mattert (g/day) & 98 & 66 & 41 & 40 \\
\hline PCy' $\ddagger$ (g/day) & 5.6 & $2 \cdot 8$ & 0.8 & 0.7 \\
\hline Artifact lignin (g/day) & 0.5 & 1.6 & 3.9 & $6 \cdot 2$ \\
\hline \multicolumn{5}{|l|}{ Mulga } \\
\hline Organic mattert (g/day) & 321 & 239 & 200 & 197 \\
\hline$P C y+\ddagger$ (g/day) & 23.6 & $14 \cdot 3$ & 3.2 & 1.8 \\
\hline Artifact lignin ( $g /$ day) & -1.4 & 2.7 & 20.0 & 22.5 \\
\hline
\end{tabular}

+ By difference from sorghum stover.

$\ddagger$ Extinction coefficient $[E(1 \%, 1 \mathrm{~cm})] \times$ flux $(\mathrm{g} /$ day $) / 124$.

than it inhibits the digestion of protein in the small intestine (Barry et al., 1986).

The artifact contained about $1.6 \mathrm{~mol}$ nitrogen $(22 \mathrm{~g})$ for each mol of flavonoid monomer (ca. $300 \mathrm{~g}$ ), therefore it immobilized several times less nitrogen than tannin-protein complexes would have done (Hagerman and Butler, 1978). The chemical nature of the artifact, its relative rates of production in the rumen, abomasum and small intestine, factors affecting its production, and whether any flavonoids are absorbed which may be toxic to the sheep or leave residues in meat, are unanswered questions.

\section{References}

Barry, T. N., Manley, T. R. and Duncan, S. J. 1986. The role of condensed tannins in the nutritional value of Lotus pedunculatus for sheep. 4 . Sites of carbohydrate and protein digestion as influenced by dietary reactive tannin concentration. British Journal of Nutrition 55: 123-127.

Bate-Smith, E. C. 1981. Astringent tannins of the leaves of Geranium species. Phytochemistry 20: 211-216.

Faichney, G. J. 1975. The use of markers to partition digestion within the gastro-intestinal tract of ruminants. In Digestion and metabolism in the ruminnit (ed. I. W. McDonald and A. C. I. Warner), pp. 277-291. University of New England Publishing Unit, Armidale, Australia.

Hagerman, A. E. and Butler, L. G. 1978. Protein precipitation method for the quantitative determination of tannins. Journal of Agricultural and Fond Chemistry 26: 809-812.

Reed, J. D., Tedla, A. and Kebede, Y. 1987. Phenolics, fibre and fibre digestibility in the crop residue from bird resistant and non-bird resistant sorghum varieties. Journal of the Science of Food and Agriculture 39: 113-121.

Van Soest, P. J. 1982. The nutritional ecology of ruminants. O. \& B. Books, Corvallis, Oregon, USA. 